\title{
REVISTAMATĒRIA
}

\section{Ethylene glycol oxidation on ternary PtRhNi/C electrocatalyst with different metal compositions}

\author{
Vera Lucia da Silva Marinho ${ }^{1,2}$, Leandro Aparecido Pocrifka ${ }^{2}$, \\ Raimundo Ribeiro Passos ${ }^{2}$
}

\footnotetext{
${ }^{1}$ Federal Institute of Amazon - IFAM - Campus Parintins CEP: 69153-000, Parintins, AM e-mail: veramarinho34@hotmail.com

${ }^{2}$ Laboratory of Electrochemistry and Energy- LEEN - PPGQ/UFAM CEP: 69077-000, Manaus, AM

e-mail: pocrifka@gmail.com; rrpassos@ufam.edu.br
}

\begin{abstract}
Direct Alcohol Fuel Cells (DAFC's) are an alternative to fuel cell systems and when is used alkaline medium this has an increase performance. The alkaline direct alcohol fuel cells (ADAFC's) have some advantages such as low-emission, high energy efficiency, improved oxidation kinetics, low crossover and in addition there is a broad range of materials that can be used as catalysts. The ethylene glycol (EG) has received attention in recent decades as an alternative fuel for ADAFC, but like others alcohols must be completed oxidized to generate full power energy. In this study we analyzed ternary $\mathrm{PtRhNi} / \mathrm{C}$ electrocatalysts with different compositions, synthesized by alcohol reduction method, and compared to Pt/C ETEK. The active area, catalytic activity and stability of catalysts for ethylene glycol oxidation in alkaline medium were studied by cyclic voltammetry, CO stripping voltammetry and chronoamperometry tests. XRD technique was applied to physical characterization and it was observed the formation of alloy. The average crystallite size was calculated from the Scherrer equation. The $\mathrm{Pt}_{92} \mathrm{Rh}_{7} \mathrm{Ni}_{1} / \mathrm{C}$ electrocatalyst shows a larger electrochemically active area and consequently higher catalytic activity for EG oxidation. This response was attributed to improvement in the synergistic effect provided by the reduction of the amount of $\mathrm{Rh}$ and $\mathrm{Ni}$ in the ternary alloy when compared to $\mathrm{Pt}_{80} \mathrm{Rh}_{15} \mathrm{Ni}_{5} / \mathrm{C}$ and $\mathrm{Pt} / \mathrm{C}$ ETEK electrocatalysts. However, $\mathrm{Pt}_{80} \mathrm{Rh}_{15} \mathrm{Ni}_{5} / \mathrm{C}$ electrocatalyst showed greater tolerance to poisoning by intermediate species due to the presence of $\mathrm{Rh}$ in greater quantity, leading to a formation of adsorbed $\mathrm{OH}$ species in potentials smaller than those for platinum.
\end{abstract}

Keywords: Ethylene glycol, electrocatalytic activity, oxidation, ternary alloy.

\section{INTRODUCTION}

The growing global energy demand over the past 50 years and concerns about the environment have stimulate research on conversion of sources of high-efficiency energy and low emissions [1,2,3]. In this context, the fuel cell technology is considered attractive in the global energy scenery as power sources for mobile, fixed or portable applications $[3,4,5,6,7,8]$. Direct Alcohol Fuel Cells (DAFC's) are an alternative to fuel cell systems, being applied at acid or basic medium. However, the acid medium limits the kinetics of the alcohols oxidation reaction, while in basic medium the kinetic is improved in both anode and cathode electrodes $[8,13,14,15]$. Thus, alkaline direct alcohol fuel cells (ADAFC's) have some advantages such as low-emission, high energy efficiency $(9,10)$, improved oxidation kinetics, low crossover and in addition there is a broad range of materials that can be used as catalysts $[8,11,12]$. Between the possible alcohols, ethylene glycol (EG) has received attention in recent decades as an alternative fuel for ADAFC because of its high theoretical energy density of $5.2 \mathrm{kWhKg}^{-1}$, easy storage and non-toxicity, beside to be abundant and originated from renewable source, such as cellulose $[2,3,4,9,10,13,16,17]$. For the other hand, in fuel cells powered by direct liquid alcohol, the fuel must be completely oxidized (or close to $100 \%$ ) to generate great power, but this still is a difficult task in ADAFC and for solve this problem researchers in different parts of the world are developing new catalysts for the full oxidation of ethylene glycol [3].

Pt-based electrocatalyst supported on carbon is commonly used for oxidation of fuel and oxygen reduction in fuel cells at low temperatures $[5,6,18]$, due to its high activity and stability in oxidize small organic molecules. However, at room temperature, ethylene glycol is not completely oxidized to $\mathrm{CO}_{2}$ because the oxidation kinetics are slow and the difficulty in breaking the $\mathrm{C}$-C bond $[10,18,19]$ making the 
oxidation a complex process due to the existence of several successive and parallel pathways $[8,14]$ producing many intermediates. Between them, the CO produced is harmful because adsorbs strongly on the $\mathrm{Pt}$ and blocks the active sites, reducing electrocatalytic activity at the anode side compromising the performance of the fuel cell $[18,20]$. It is known that the partial oxidation in acidic medium also produces intermediates and main products with two carbons such as glycolaldehyde, glycolic acid, glyoxal, glyoxylic acid and oxalic acid $[1,10,13]$. Beside this, other studies developed in alkaline medium to identify the products of the EG oxidation detected also glycolate, oxalate and carbonate as main products [19].

Thus, Pt monometallic electrocatalyst is poorly efficient at complete oxidizing adsorbed intermediates in the platinum active sites [14]. Aiming to solve this problem researchers are developing new bi and/or trimetallic catalysts for the complete oxidation of ethylene glycol [3,8]. The alloys are seen as more tolerant to the $\mathrm{CO}$ poisoning, since the presence of a second or third metal as co-catalyst modifies the atomic structure and the valence of the $d$ orbitals of the $\mathrm{Pt}[21,22,23]$. These co-catalysts weaken the adsorption energy of $\mathrm{CO}$ and facilitate the cleavage of the $\mathrm{C}-\mathrm{C}$ bond of the adsorbed alcohols $[21,22,23]$.

This work studied the physical and electrochemical characteristics of $\mathrm{PtRhNi} / \mathrm{C}$ ternary alloys with different atomic ratios for ethylene glycol oxidation at alkaline medium. The electrocatalysts were synthesized by a chemical reducing method and physically characterized by XRD and TEM. The electrochemical characterization was made by cyclic voltammetry and chronoamperometry techniques.

\section{MATERIALS AND METHODS}

The electrocatalysts $\mathrm{PtRhNi} / \mathrm{C}$ were prepared using $\mathrm{H}_{2} \mathrm{PtCl}_{6} \cdot 6 \mathrm{H}_{2} \mathrm{O}$ ( $\geq 99,9 \%$,Sigma-Aldrich), $\mathrm{RhCl}_{3} .3 \mathrm{H}_{2} \mathrm{O}$ (38-40\% Rh, Sigma-Aldrich) and $\mathrm{NiCl}_{2} \cdot 6 \mathrm{H}_{2} \mathrm{O}$ ((ReagentPlus ${ }^{\circledR}, \geq 99 \%$, Sigma-Aldrich) as metal sources, ethylene glycol (99,5\%, Merck) as solvent and reducing agent [24] and Vulcan XC72R carbon as a support. The reducing method was by alcoholic reducing method [25]. All electrocatalysts had loading of $40 \%$ of metal on carbon. Initially, the metals precursors were dissolved in ethylene glycol solution (75:25) followed by the addition of the carbon support. The resulting mixture was refluxed for $2 \mathrm{~h}$ at $130^{\circ} \mathrm{C}$. At the end of reflux, the mixture was filtered and then the filtrate was taken to dry at $70^{\circ} \mathrm{C}$ for $2 \mathrm{~h}$, for posterior maceration. The different atomic proportions adopted for Pt:Rh:Ni were 80:15:5 and 92:7:1, from now on called the $\mathrm{EC}_{\mathrm{A}}$ and $\mathrm{EC}_{\mathrm{B}}$, respectively.

The crystalline structures of these powder supported electrocatalysts were determined by X-ray diffraction (XRD) technique. The results were obtained using a X-ray diffractometer BRUKER Model Phaser D2 diffractometer (Bruker AXS, Karlsruhe, Germany) equipped with a slit of $0.6 \mathrm{~mm} \mathrm{Cu}$ tube radiation ( $\mathrm{K}_{\alpha}$ $=0.15406 \mathrm{~nm}, 30 \mathrm{kV}, 10 \mathrm{~mA}$ ) and a $\mathrm{Cu}$ filter. The samples were analyzed from 10 to $90^{\circ}$ Bragg angles (20) swept at $0.02{ }^{\circ}$ scan speed, with intensities recorded at $1 \mathrm{~s}$ for every step.

Transmission electron microscopy (TEM) analysis was carried out with a LEO EM 109, Carls Zeis, at the Thematic Laboratory of Optical and Electron Microscopy of the National Research Institute of the Amazon - INPA, working at an acceleration voltage of $120 \mathrm{keV}$. The samples were prepared by dispersing the catalysts in a solution of isopropanol and water and sonicating for a short time. Drops of this dispersion were deposited onto carbon coated copper grids and dried before analysis.

Electrochemical studies by cyclic voltammetry and chronoamperometry were performed in a glass half-cell of three electrodes using a potentiostat/galvanostat Model VersaSTAT 4 (Princeton Applied Research, USA). A platinum plate $\left(\sim 1 \mathrm{~cm}^{2}\right)$ and a hydrogen electrode (RHE) were used as counter electrode and reference electrode, respectively. The working electrode support was an Au disk (3mm diameter) wrapped in a Teflon cylinder. For the preparation of the working electrode, $2 \mathrm{mg}$ of the electrocatalyst were dispersed in a suspension of $20 \mu \mathrm{L}$ of a Nafion solution (5\% in weight, DuPont) and $400 \mu \mathrm{l}$ of isopropyl alcohol under ultrasonic agitation for 30 minutes. An aliquot of this suspension was dropped on the polished surface of Au electrode and dried at room temperature for 5 minutes.

Cyclic voltammetry (CV) of each electrocatalyst was carried out between 0.05 and $1.1 \mathrm{~V} v s$. RHE in 0.5 mol. $\mathrm{L}^{-1}$ of $\mathrm{KOH}$ with and without alcohol at room temperature. All electrochemical experiments were performed in a KOH 0.5 mol. $\mathrm{L}^{-1}$ solution (Merck, $90 \%$ ) + 1.0 mol. $\mathrm{L}^{-1}$ of ethylene glycol (EG Merck, $99.5 \%$ ). The electrochemical stabilities were obtained by chronoamperometry for each electrocatalyst $\mathrm{Pt}_{80} \mathrm{Rh}_{15} \mathrm{Ni}_{5} / \mathrm{C}$ and $\mathrm{Pt}_{92} \mathrm{Rh}_{7} \mathrm{Ni}_{1} / \mathrm{C}$ in this same solution at room temperature saturated with $\mathrm{N}_{2}$ gaseous. The electrochemically active surface area (EASA) of the electrocatalysts was determined by CO-stripping measurements: a CO monolayer coating on the electrode was achieved by bubbling $\mathrm{CO}$ into the electrolyte for $15 \mathrm{~min}$, while a potential of $0.05 \mathrm{~V}$ was applied to the immersed electrode. After that, $\mathrm{N}_{2}$ was passed through the solution for 20 min for removing all free $\mathrm{CO}$ in the solution, and $\mathrm{CV}$ was performed at a scan rate of $50 \mathrm{mV} \mathrm{s}^{-1}$ in the potential range of 0.05 e $1.1 \mathrm{~V}$. 


\section{RESULTS AND DISCUSSION}

\subsection{Physical Characterization}

Fig. 1 shows $\mathrm{x}$-ray diffractograms for $\mathrm{PtRhNi} / \mathrm{C}$ electrocatalysts prepared with two different atomic ratios between the metals Pt:Rh:Ni on carbon. The diffraction peak at approximately $24.9^{\circ}$ corresponds to the plane (002) for hexagonal structure of carbon support used in the electrocatalysts. The XRD pattern for the $\mathrm{PtRhNi} / \mathrm{C}$ electrocatalyst for $\mathrm{EC}_{\mathrm{A}}$ showed peaks with $2 \theta$ values corresponding to $40.21,46.70,68.66$ and $82.66^{\circ}$ while for $\mathrm{EC}_{\mathrm{B}}$ showed peaks corresponding to $2 \theta$ in $39.86,46.02,67.41$ and $81.37^{\circ}$. These values can be attributed to the $f c c$ structure of $\mathrm{Pt}(111),(200),(220)$ and (311), respectively. Analyzing the database for individual metals, Pt (ICDS, 426990) and Rh (ICDS, 426969), there is a shift to higher angles than Pt pure, indicating the incorporation of $\mathrm{Rh}$ and $\mathrm{Ni}$ in the Pt metal structure and the formation of PtRhNi/C leagues in different compositions $[26,27,28]$. There were no diffraction peaks for $\mathrm{Rh}, \mathrm{Ni}$ and/or their oxides, however, these metals may be present in amorphous form [28, 29].

The new lattice parameter values for $\mathrm{PtRhNi} / \mathrm{C}$ electrocatalysts in the different proportions 80:15:05 and 92:7:1 were 3.86 and $3.90 \AA$, respectively. These parameters values are lower than the Pt lattice parameter $(3.98 \AA)$, indicating the formation of alloys as said before $[26,27,28,29]$. The average particle size of the crystallites were estimated using Scherrer's equation from the (200) Pt peak [27,30] and it was found $\mathrm{PtRhNi} / \mathrm{C}$ values of $2.82 \mathrm{~nm}$ for $\mathrm{EC}_{\mathrm{A}}$ and $2.31 \mathrm{~nm}$ for $\mathrm{EC}_{\mathrm{B}}$.

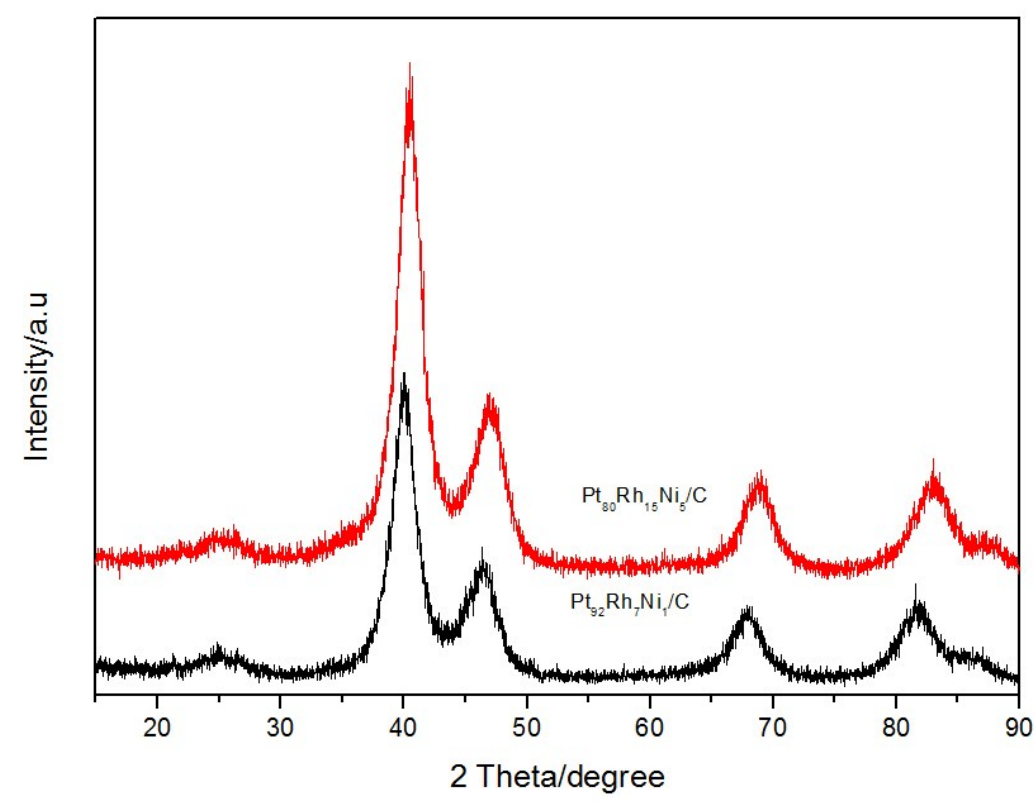

Figure 1: XRD pattern for PtRhNi/C electrocatalysts with different metal compositions.

The morphology and structure of the typical electrocatalysts were examined by TEM measurements. The TEM images of different electrocatalysts are shown in Fig. 2. In Fig. 2 A, the $\mathrm{Pt}_{80} \mathrm{Rh}_{15} \mathrm{Ni}_{5} / \mathrm{C}\left(\mathrm{EC}_{\mathrm{A}}\right)$ electrocatalysts contains the uniform and dispersed nanoparticles on carbon support. However, it is observed, in Fig. 2B, that there was a certain agglomeration of the particles in which the overlapping of the particles is visible for $\mathrm{Pt}_{92} \mathrm{Rh}_{7} \mathrm{Ni}_{1} / \mathrm{C}\left(\mathrm{EC}_{\mathrm{B}}\right)$ electrocatalyst . The particle size distribution histogram beside in Fig. $2 \mathrm{~A}$ and $\mathrm{B}$, obtained by counting about 120 nanoparticles in the TEM image, shows that the average diameters are $15.00 \mathrm{~nm}$ for $\left(\mathrm{EC}_{\mathrm{A}}\right)$ and $14.00 \mathrm{~nm}$ for $\left(\mathrm{EC}_{\mathrm{B}}\right)$, respectively. No significant differences were observed between the particle sizes in the electrocatalysts with the change in the atomic composition between the $\mathrm{Pt}, \mathrm{Rh}$ and $\mathrm{Ni}$ metals which means that the particle size effect is a parameter that will not influence the electrocatalytic activity. 

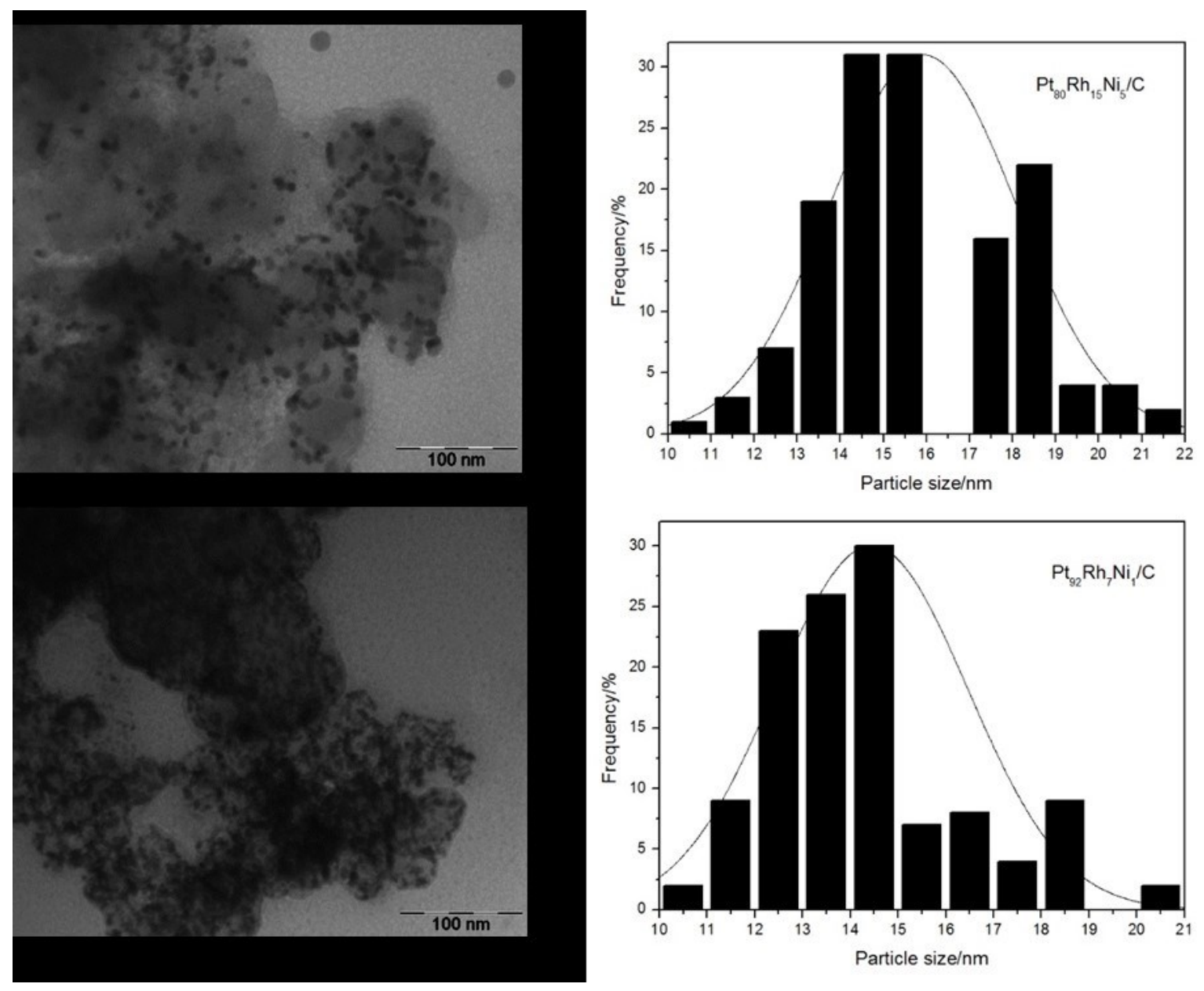

Figure 2: Representative TEM images of the $\mathrm{Pt}_{80} \mathrm{Rh}_{15} \mathrm{Ni}_{5} / \mathrm{C}$ (A) and $\mathrm{Pt}_{92} \mathrm{Rh}_{7} \mathrm{Ni}_{1} / \mathrm{C}$ (B) electrocatalysts, together with particle-size distributions.

\subsection{EG Oxidation on PtRhNi/C}

The electrochemically active surface area (EASA) is related to the number of active sites available in the catalyst [31,32]. The EASA's for the PtRhNi/C electrocatalysts with different proportions are showed at Fig. $3 \mathrm{~A}$ and $\mathrm{B}$ and were estimated from CO stripping voltammetry tests. The EASA is calculated according to the Eq. (1) $[11,31]$ :

$$
E A S A=\frac{Q}{(420 \times m)}
$$

where $\mathrm{Q}$ is the charge for $\mathrm{CO}$ desorption electrooxidation $(\mu \mathrm{C}), m$ is the total amount of metal $(\mathrm{mg})$ on the electrode surface, and 420 is the charge required to oxidize a monolayer of $\mathrm{CO}$ adsorbed on the catalyst surface $\left(\mu \mathrm{C} . \mathrm{cm}^{-2}\right)[11,31]$.

The EASA of the PtRhNi/C electrocatalysts $\left(\mathrm{EC}_{\mathrm{A}}\right.$ and $\left.\mathrm{EC}_{\mathrm{B}}\right)$ were 28.56 and $31.20 \mathrm{~m}^{2} \cdot \mathrm{g}^{-1}$ metal, respectively, under the same conditions. It is observed that the $\mathrm{PtRhNi} / \mathrm{C}$ electrocatalyst $\left(\mathrm{EC}_{\mathrm{B}}\right)$ showed an active area value higher than $\mathrm{PtRhNi} / \mathrm{C}\left(\mathrm{EC}_{\mathrm{A}}\right)$, meaning greater number of active sites for $\mathrm{EC}_{\mathrm{B}}$. In Figure 3 ( $\mathrm{A}$ and $\mathrm{B}$ ) is also found that $\mathrm{CO}$ oxidation onset potential is higher for a smaller Pt quantity in the electrocatalyst with values 0.49 and $0.43 \mathrm{~V}$, respectively. Higher active area and lower $\mathrm{CO}$ oxidation onset potential are important parameters for electrocatalytic performance $[11,31,33]$. The corresponding maximum catalytic currents were normalized with the EASA and the loading amount of metals. 

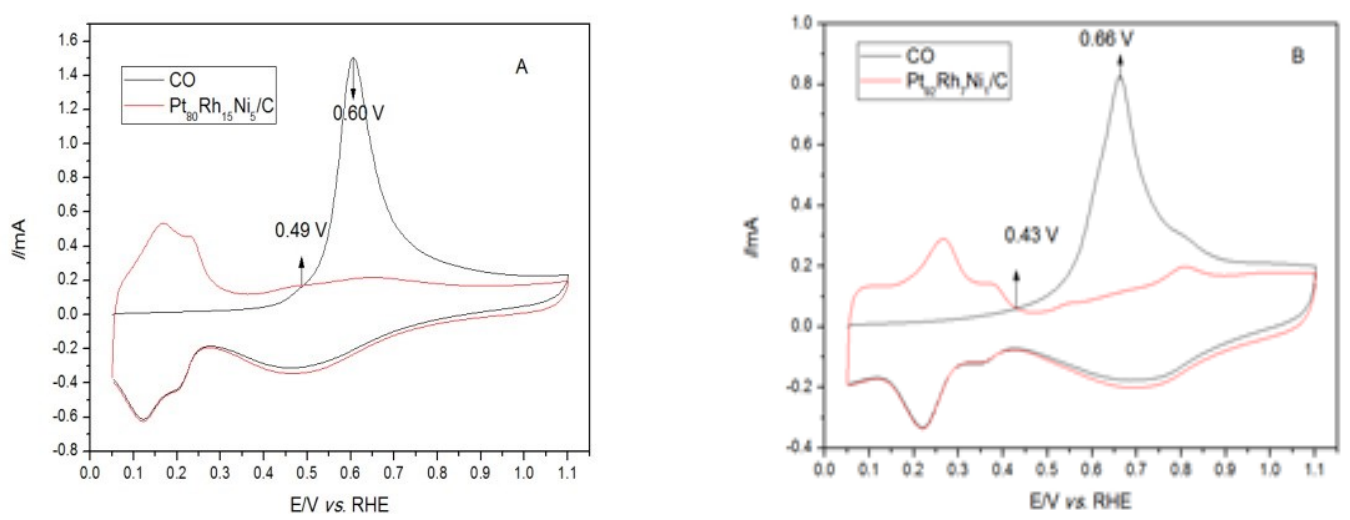

Figure 3: CO Stripping voltammetry for PtRhNi/C electrocatalysts, $\mathrm{EC}_{\mathrm{A}}(\mathrm{A})$ and $\mathrm{EC}_{\mathrm{B}}(\mathrm{B}) .0 .5 \mathrm{~mol} \cdot \mathrm{L}^{-1} \mathrm{KOH}$ electrolyte and scan speed 0.05 V.s.

Fig. 4 contains the results of cyclic voltammetry of the $\mathrm{PtRhNi} / \mathrm{C}$ electrocatalysts performed in $1.0 \mathrm{~mol} . \mathrm{L}^{-1} \mathrm{KOH}$ for a range potential of 0.05 to $1.1 \mathrm{~V}$ (vs. RHE) without the presence of EG. This figure is important to characterize the interactions between metal surfaces with hydrogen and examining the electrochemical potential range in which the stabilization of the material occurs. From the cyclic voltammograms of $\mathrm{PtRhNi} / \mathrm{C}$ electrocatalysts $\left(\mathrm{EC}_{\mathrm{A}}\right.$ and $\left.\mathrm{EC}_{\mathrm{B}}\right)$, it was found that the adsorption peaks and hydrogen desorption were better defined for the catalyst with higher amounts of $\mathrm{Pt}\left(\mathrm{EC}_{\mathrm{B}}\right)$, while $\mathrm{EC}_{\mathrm{A}}$ presents wider peaks and electrical double layer region undefined. This characteristic is attributed to electrocatalysts supported on carbon containing transition metals [34] and it may be happens as a result of structural modifications of Pt due to the interaction with $\mathrm{Rh}$ and $\mathrm{Ni}$ atoms [28]. Both electrocatalysts have well defined oxide reduction regions, but the oxide region was more evident in the electrocatalyst with higher amounts of $\mathrm{Pt}$, indicating that $\mathrm{EC}_{\mathrm{B}}$ has more active sites on the surface [35]. The Pt smaller amount effect in both adsorption and desorption regions of hydrogen and the undefined double electric layer seen for the $\mathrm{EC}_{\mathrm{A}}$ also might be attributed to the higher amount of rhodium compared to $\mathrm{Pt}_{92} \mathrm{Rh}_{7} \mathrm{Ni}_{1} / \mathrm{C}$ [27].

The catalytic activities of the Pt/C ETEK (as reference material) and PtRhNi/C electrocatalysts are shown in Fig. 5, from CV data for ethylene glycol electro-oxidation (1.0 mol. $\left.\mathrm{L}^{-1}\right)$ reaction in 0.5 mol. $\mathrm{L}^{-1}$ $\mathrm{KOH}$, in a range potential of 0.05 to $1.1 \mathrm{~V}$ (vs. RHE). The metal amounts (in $m g$ ) present in each working electrode were $0.031,0.031$ and $0.032 \mathrm{mg}$ for $\mathrm{Pt} / \mathrm{C} \mathrm{ETEK}, \mathrm{EC}_{\mathrm{A}} / \mathrm{C}$ and $\mathrm{EC}_{\mathrm{B}} / \mathrm{C}$, respectively. It is observed in the voltammograms two defined peaks, one in anodic currents at positive scan related to EG oxidation and an another, at negative scan, for oxidation of intermediate species adsorbed on the electrocatalyst surface $[2,3,28,31,36]$. The forward scan peak current density $\left(\mathrm{j}_{\mathrm{d}}\right)$ were $0.70,1.87$ and $1.84 \mathrm{mAcm}^{-2}$ for $\mathrm{EC}_{\mathrm{A}}, \mathrm{EC}_{\mathrm{B}}$ and $\mathrm{Pt} / \mathrm{C}$ ETEK, respectively. The PtRhNi/C $\left(\mathrm{EC}_{\mathrm{B}}\right)$ electrocatalyst showed current density twice higher that the $\mathrm{EC}_{\mathrm{A}}$ electrocatalyst and slightly higher than $\mathrm{Pt} / \mathrm{C}$ ETEK. These values are in agreement with the results obtained for the active area, because the electrocatalyst presents a higher active area $31.20 \mathrm{~m}^{2} \mathrm{~g}^{-1}$ metal. Besides that, the $\mathrm{EC}_{\mathrm{B}}$ electrocatalyst presents a well-defined peak, compared to the others that are more broadens. This might shows that the process occurring in the catalyst surface is due to a synergetic effect between the metals.

The oxidation onset potential $\left(\mathrm{E}_{\mathrm{o}}\right)$ is a useful parameter to identify the best electrocatalyst composition for the alcohol oxidation, being considered better that presents the lowest oxidation onset potential [2,34]. The onset potentials for the oxidation of ethylene glycol were 0.40 and $0.45 \mathrm{~V}$ for $\mathrm{EC}_{\mathrm{B}}$ electrocatalyst and $\mathrm{EC}_{\mathrm{A}}$ and Pt/C ETEK catalyst, respectively. As stated before, the lower onset potential is a result that can be attributed to the higher interaction between $\mathrm{Rh}, \mathrm{Ni}$ and $\mathrm{Pt}$ metals in the ternary alloy, as $\mathrm{Rh}$ and $\mathrm{Ni}$ are oxophilic metals and their presence in a smallest quantity contribute positively to the synergism between them. 


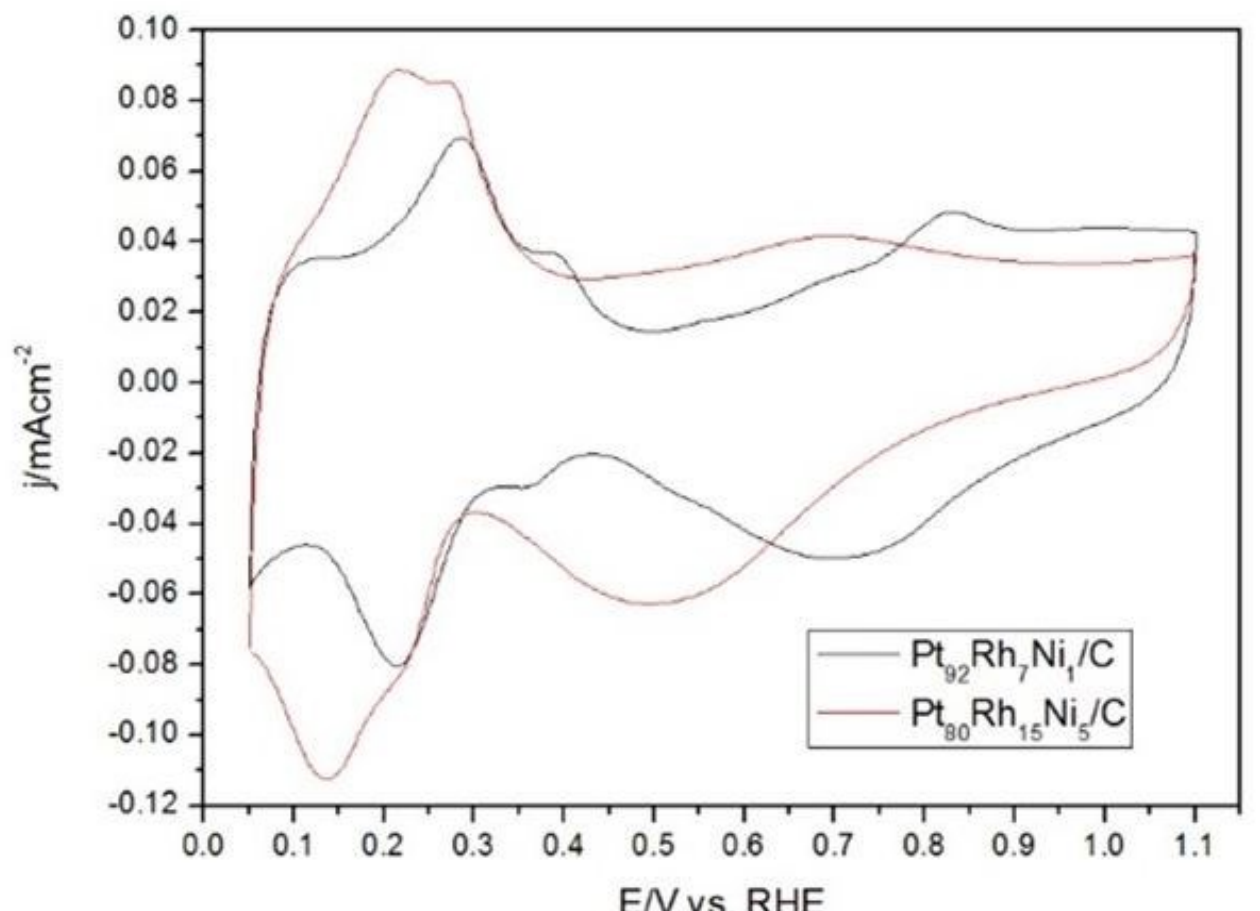

Figure 4: Cyclic voltammograms for $\mathrm{PtRhNi} / \mathrm{C}$ electrocatalysts $\left(\mathrm{EC}_{\mathrm{A}}\right.$ and $\left.\mathrm{EC}_{\mathrm{B}}\right) .0 .5 \mathrm{~mol} \cdot \mathrm{L}^{-1} \mathrm{KOH}$ with a scan rate $0.05 \mathrm{~V} . \mathrm{s}^{-1}$.

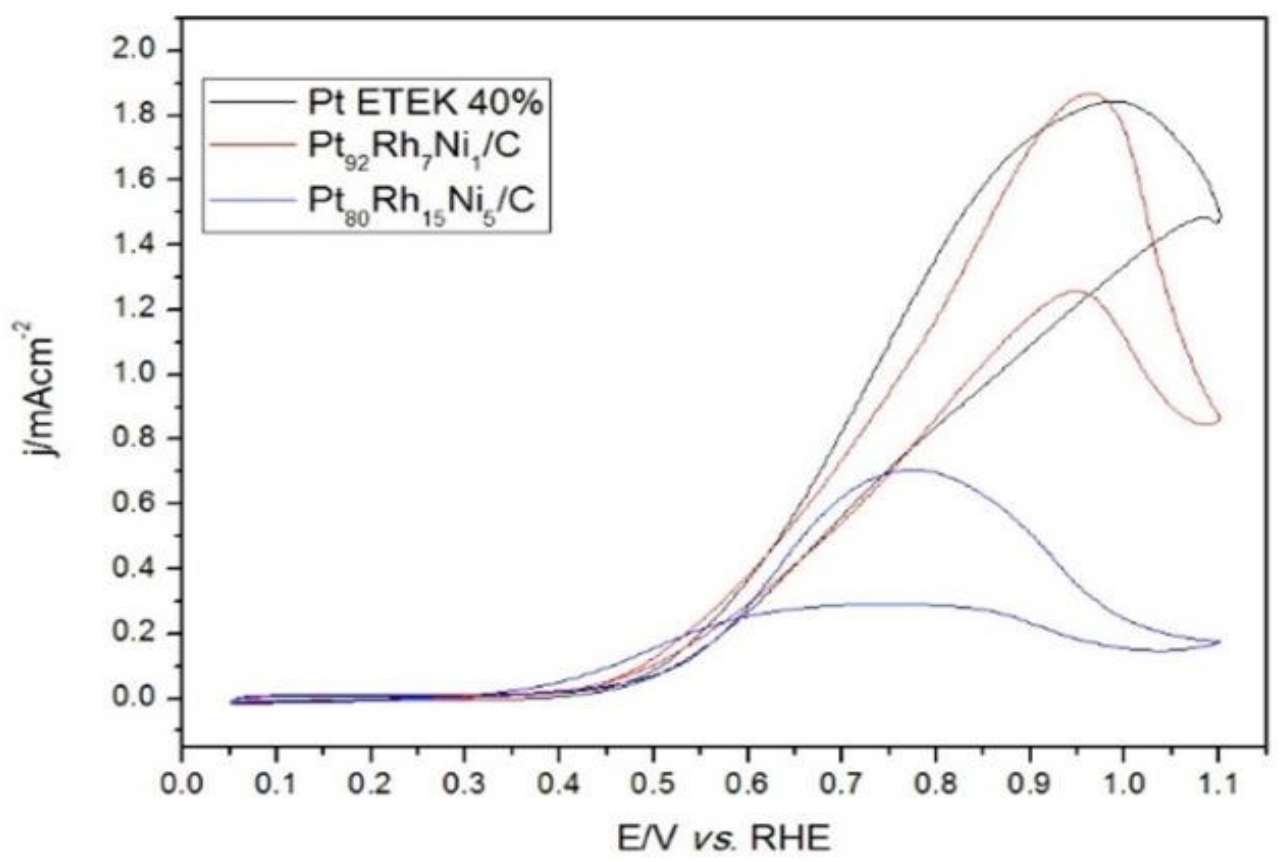

Figure 5: Cyclic Voltammograms for $\mathrm{Pt} / \mathrm{C} \mathrm{ETEK}$ and $\mathrm{PtRhNi} / \mathrm{C}\left(\mathrm{EC}_{\mathrm{A}}\right.$ and $\left.\mathrm{EC}_{\mathrm{B}}\right)$ electrocatalysts in the presence 1.0 mol.L $\mathrm{L}^{-1}$ EG in $0.5 \mathrm{~mol} . \mathrm{L}^{-1} \mathrm{KOH}$. Scanning speed $0.05 \mathrm{~V} . \mathrm{s}^{-1}$. 
The peak current density in the forward direction $\left(\mathrm{j}_{\mathrm{f}}\right)$ is attributed to the alcohol oxidation reactions during the positive scan. The peak current density in the reverse direction $\left(\mathrm{j}_{\mathrm{r}}\right)$ is due to the oxidation of carbonaceous intermediates incompletely oxidized on the surface of the electrocatalysts during the negative scan. The relation $j_{\mathrm{f}} / j_{\mathrm{r}}$ is generally used to evaluate the electrocatalyst tolerance to poisoning by the intermediate carbonaceous species $[28,37]$. The $\mathrm{j}_{\mathrm{f}} / \mathrm{j}_{\mathrm{r}}$ obtained here was 2.33 to $\mathrm{PtRhNi} / \mathrm{C}\left(\mathrm{EC}_{\mathrm{A}}\right), 1.50$ to $\mathrm{PtRhNi} / \mathrm{C}\left(\mathrm{EC}_{\mathrm{B}}\right)$ and 1.24 to $\mathrm{Pt} / \mathrm{C}$ ETEK. These values indicate that there was less accumulation of intermediate species in the $\mathrm{Pt}_{80} \mathrm{Rh}_{15} \mathrm{Ni}_{5} / \mathrm{C}$ electrocatalyst during the electrooxidation processes of ethylene glycol. This result can be attributed to the presence of $\mathrm{Rh}$ and $\mathrm{Ni}$ in greater amounts in the metal alloy. These metals provide the formation of more adsorbed $\mathrm{OH}$ species to make the oxidation of the intermediates more efficiently and leave free the active sites on the surface of the electrocatalyst [27,38]. Besides that, might be have a straight relation between the percentages of metals present in the catalyst, because the higher value $\mathrm{j}_{\mathrm{f}} / \mathrm{j}_{\mathrm{r}}$ indicates a most effective effect for the oxidation of $\mathrm{CO}$ to $\mathrm{CO}_{2}$ and the removal of intermediates adsorbed on the surface of the electrocatalyst $[28,33,37]$ but, for the other hand, leads to lowest current peak density.

The activity and stability of the $\mathrm{Pt} / \mathrm{C}$ ETEK, $\mathrm{Pt}_{80} \mathrm{Rh}_{15} \mathrm{Ni}_{5} / \mathrm{C}$ and $\mathrm{Pt}_{92} \mathrm{Rh}_{7} \mathrm{Ni}_{1} / \mathrm{C}$ electrocatalysts and the poisoning level of surfaces by the adsorption of intermediate species produced during the EG oxidation reaction were evaluated by chronoamperometry tests conducted at $0.6 \mathrm{~V}$ for $1800 \mathrm{~s}$ (Fig. 6). Pt/C ETEK and $\mathrm{PtRhNi} / \mathrm{C}\left(\mathrm{EC}_{\mathrm{A}}\right.$ and $\left.\mathrm{EC}_{\mathrm{B}}\right)$ electrocatalysts were stable to ethylene glycol oxidation, but the current density declined slowly at 100 and 120 seconds for $\mathrm{Pt} / \mathrm{C}$ ETEK and $\mathrm{PtRhNi} / \mathrm{C}\left(\mathrm{EC}_{\mathrm{A}}\right)$, respectively. This decrease in the current density is due to the presence of intermediate species [11,31].

However, PtRhNi/C $\left(\mathrm{EC}_{\mathrm{B}}\right)$ electrocatalyst showed higher current density compared to them indicating higher catalytic activity even though has $\mathrm{j}_{\mathrm{f}} / \mathrm{j}_{\mathrm{r}}$ value of 1.50 , as can be seen in Table 1 . As above, the synergetic effect generated by the metals when are present in this percentage in the ternary league contributes more to the activity of the electrocatalyst [34] than to the other composition. Nevertheless, the lower loss of current density is for $\mathrm{Pt}_{80} \mathrm{Rh}_{15} \mathrm{Ni}_{5} / \mathrm{C}$ and corresponds to the value of the $\mathrm{j}_{\mathrm{d}} \mathrm{j}_{\mathrm{r}}$ presented in Table 1 . Thus, $\mathrm{Rh}$ and $\mathrm{Ni}$ in higher amounts favors kinetically the formation of oxygenated species which can leads to the oxidation of the adsorbed intermediate species releasing quickly the active sites [38] and the fact that the peak of reduction of $\mathrm{Rh}$ oxides appears in potentials inferior to those of $\mathrm{Pt}$ indicating that its oxide is more stable [27].

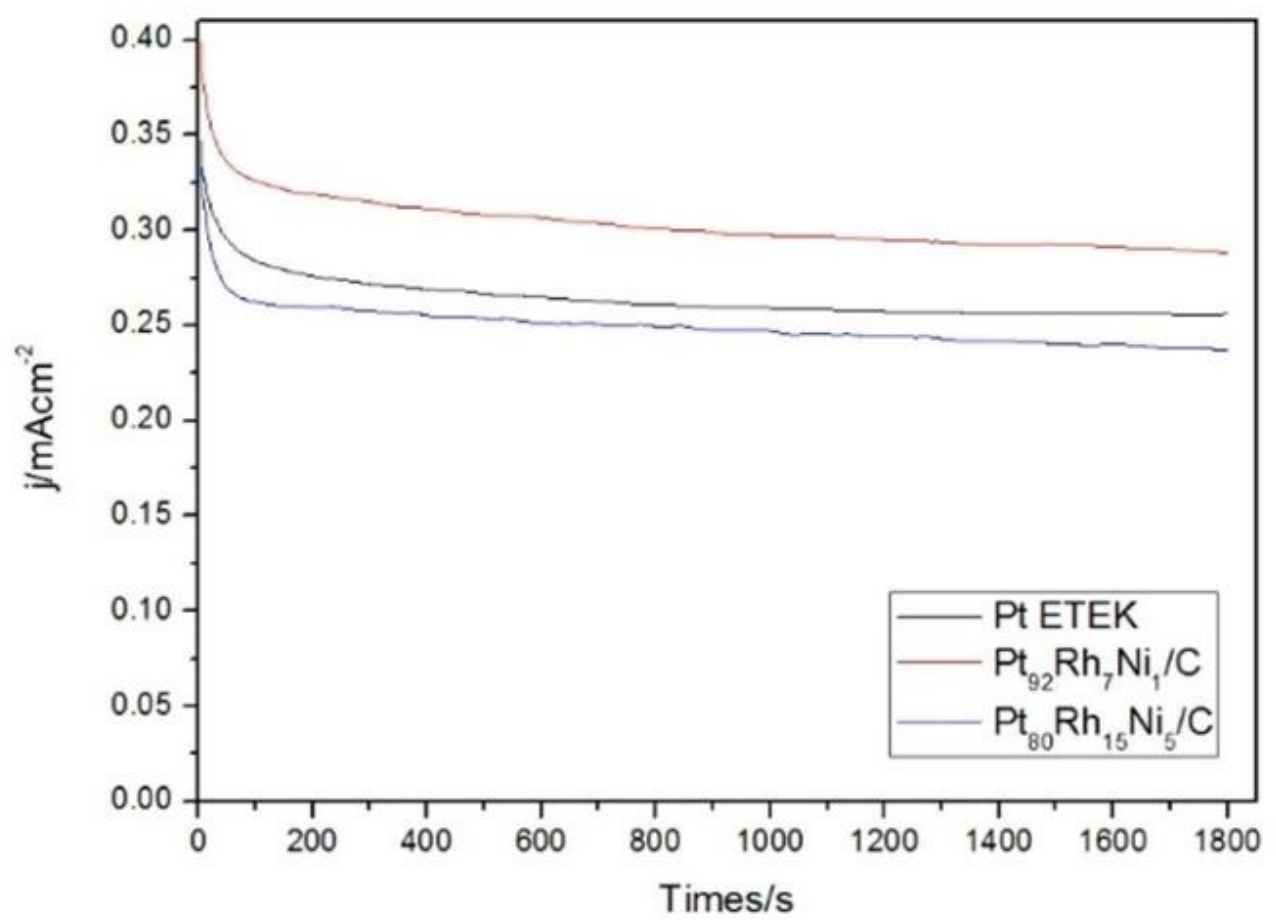

Figure 6: Chronoamperometry curves at $0.6 \mathrm{~V}$ for $\mathrm{PtRhNi} / \mathrm{C}\left(\mathrm{EC}_{\mathrm{A}}\right.$ and $\left.\mathrm{EC}_{\mathrm{B}}\right)$ electrocatalysts in presence of $1.0 \mathrm{~mol} . \mathrm{L}^{-1}$ EG and 0.5 mol.L $\mathrm{L}^{-1} \mathrm{KOH}$. 
Table 1: Electrochemical Performance parameters for Pt/C ETEK and PtRhNi/C electrocatalysts at 0.5 mol. $\mathrm{L}^{-1} \mathrm{KOH}$.

\begin{tabular}{cccccccc}
\hline Electrocatalysts & Metal \% & EASA $\left(\mathbf{m}^{\mathbf{2}} \mathbf{g}^{-\mathbf{1}}\right)$ & $\mathbf{E}_{\mathbf{0}}(\mathbf{V})$ & $\mathbf{E}_{\mathbf{f}}(\mathbf{V})$ & $\mathbf{j}_{\mathbf{f}}\left(\mathbf{m A} . \mathbf{c m}^{2}\right)$ & $\mathbf{j}_{\mathbf{r}}\left(\mathbf{m A} / \mathbf{c m}^{2}\right)$ & $\mathbf{j}_{\mathbf{f}} / \mathbf{j}_{\mathbf{r}}$ \\
\hline PtRhNi/C & $80: 15: 5$ & 28.56 & 0.45 & 0.77 & 0.70 & 0.30 & 2.33 \\
PtRhNi/C & $92: 7: 1$ & 31.20 & 0.40 & 0.96 & 1.87 & 1.25 & 1.50 \\
Pt/C ETEK & 100 & 24.16 & 0.45 & 0.99 & 1.84 & 1.48 & 1.24 \\
\hline
\end{tabular}

\section{CONCLUSIONS}

$\mathrm{PtRhNi} / \mathrm{C}$ electrocatalysts in different compositions showed activity to the ethylene glycol oxidation. The $\mathrm{Pt}_{92} \mathrm{Rh}_{7} \mathrm{Ni}_{1} / \mathrm{C}$ electrocatalyst shows a larger electrochemically active area and consequently higher catalytic activity for EG oxidation. This response was attributed to improvement in the synergistic effect provided by the reduction of the amount of $\mathrm{Rh}$ and $\mathrm{Ni}$ in the ternary alloy when compared to $\mathrm{Pt}_{80} \mathrm{Rh}_{15} \mathrm{Ni}_{5} / \mathrm{C}$ and $\mathrm{Pt} / \mathrm{C}$ ETEK electrocatalysts. However, $\mathrm{Pt}_{80} \mathrm{Rh}_{15} \mathrm{Ni}_{5} / \mathrm{C}$ electrocatalyst showed greater tolerance to poisoning by intermediate species due to the presence of $\mathrm{Rh}$ in greater quantity, leading to a formation of adsorbed $\mathrm{OH}$ species in potentials smaller than those for platinum.

\section{ACKNOWLEDGMENTS}

The authors acknowledge financial assistance from CNPq (Grant \#456336/2013-3), FAPEAM, CAPES, IFAM and UFAM.

\section{BIBLIOGRAPHY}

[1] YUE, H., ZHAO, Y., MA, X., et al., "Ethylene glycol: properties, synthesis, and applications", Chemical Society Reviews 41, pp. 4218-4244, 2012.

[2] KIM, H. J., CHOI, S. M., GREEN, S., et al., "Highly active and stable PtRuSn/C catalyst for electrooxidations of ethylene glycol and glycerol", Applied Catalysis B: Environmental 101, pp. 366-375, 2011.

[3] SEROV, A., KWAK, C., "Recent achievements in direct ethylene glycol fuel cells (DEGFC)", Applied Catalysis B: Environmental 97, pp. 1-12, 2010.

[4] FASHEDEMI, O. O., MILLER, H., MARCHIONNI, A., et al., "Electro-oxidation of ethylene glycol and glycerol at palladium-decorated FeCo@Fe core-shell nanocatalysts for alkaline direct alcohol fuel cells: Functionalized MWCNT supports and impact on product selectivity". Journal of Materials Chemistry A 3. pp. 7145-7156, 2015.

[5] XU, Y., HAN, L., "Comprehensive understanding of electro-oxidation of ethylene glycol”, International Journal of Hydrogen Energy 39, pp. 7278-7290, 2014.

[6] RAMULIFHO, T., OZOEMENA, K. I., MODIBEDI, R. M., et al., "Electrocatalytic oxidation of ethylene glycol at palladium-bimetallic nanocatalysts (PdSn and PdNi) supported on sulfonate-functionalised multiwalled carbon nanotubes", Journal of Electroanalytical Chemistry 692, pp. 26-30, 2013.

[7] YU, E. H., KREWER, U., SCOTT, K, "Principles and Materials Aspects of Direct Alkaline Alcohol Fuel Cells”, Energies 3, pp. 1499-1528, 2010.

[8] ANTOLINI, E., GONZALEZ, E.R., “Alkaline direct alcohol fuel cells”, Journal of Power Sources 195, pp. 3431-3450, 2010.

[9] TRAVITSKY, N., BURSTEIN, L., ROSENBERG, Y., et al., "Effect of methanol, ethylene glycol and their oxidation by-products on the activity of Pt-based oxygen-reduction catalysts", Journal of Power Sources 194, pp. 161-167, 2009.

[10] KOSAKA, F., OSHIMA, Y., OTOMO, J., "Electrochemical performance for the electro-oxidation of ethylene glycol on a carbon-supported platinum catalyst at intermediate temperature", Electrochimica Acta 56, pp. 10093-10100, 2011.

[11] LI, S. S., HU, Y. Y., FENG, J. J., et al., "Rapid room-temperature synthesis of Pd nanodendrites on reduced graphene oxide for catalytic oxidation of ethylene glycol and glycerol", International Journal of 
Hydrogen Energy 39, pp. 3730-3738, 2014.

[12] KIM, Y., KIM, H., KIM, W. B., "PtAg nanotubes for electrooxidation of ethylene glycol and glycerol in alkaline media", Electrochemistry Communications 46, pp. 36-39, 2014.

[13] FALASE, A., MAIN, M., GARCIA, K., et al., "Electrooxidation of ethylene glycol and glycerol by platinum-based binary and ternary nano-structured catalysts", Electrochimica Acta 66, pp. 295-301, 2012.

[14] XIN, L., ZHANG, Z., QI, J., CHADDERDON, D., et al., "Electrocatalytic oxidation of ethylene glycol (EG) on supported $\mathrm{Pt}$ and Au catalysts in alkaline media: Reaction pathway investigation in three-electrode cell and fuel cell reactors", Applied Catalysis B: Environmental 125, pp. 85- 94, 2012.

[15] JIN, C., SONG, Y., CHEN, Z., "A comparative study of the electrocatalytic oxidation of ethylene glycol on PtAu nanocomposite catalysts in alkaline, neutral and acidic media" Electrochimica Acta 54, pp. 41364140, 2009.

[16] FASHEDEMI, O. O., OZOEMENA, K. I., "Comparative electrocatalytic oxidation of ethanol, ethylene glycol andglycerol in alkaline medium at Pd-decorated $\mathrm{FeCo} @ \mathrm{Fe} / \mathrm{C}$ core-shell nanocatalysts" Electrochimica Acta 128, pp. 279-286, 2014.

[17] FIGUEIREDO, M. C., SORSA, O., DOAN, N., et al., "Direct alcohol fuel cells: Increasing platinum performance by modification with sp-group metals", Journal of Power Sources 275, pp. 341-350, 2015.

[18] SIEBEN, J.M., DUARTE, M.M.E., "Methanol, ethanol and ethylene glycol electro-oxidation at Pt and Pt-Ru catalysts electrodeposited over oxidized carbon nanotubes", International Journal of Hydrogen Energy 37, pp. 994-9947, 2012.

[19] MIYAZAKI, K., MATSUMIYA, T., ABE, T., KURATA, H., et al., "Electrochemical oxidation of ethylene glycol on Pt-based catalysts in alcaline solutions and quantitative analysis of intermediate products", Electrochimica Acta 56, pp. 7610- 7614, 2011.

[20] MARTINS, C. A., FERNÁNDEZ, P. S., TROIANI, H. E., et al., "Aglomeration and cleaning of Carbon Supported Palladium Nanoparticles in Electrochemical", Environment Electrocatalysis 5, pp.204-212, 2014.

[21] GONZÁLEZ-QUIJANO, D., PECH-RODRÍGUEZ, W. J., ESCALANTE-GARCÍA, J. I., et al., "Electrocatalysts for ethanol and ethylene glycol oxidation reactions. Part I: effects of the polyol synthesis conditions on the characteristics and catalytic activity of Pt-Sn/C anodes", International Journal Hydrogen Energy 39, pp. 16676-16685, 2014.

[22] SIEBEN, J.M., DUARTE, M.M.E., "Nanostructured Pt and Pt-Sn catalysts supported on oxidized carbon nanotubes for ethanol and ethylene glycol electro-oxidation", International Journal Hydrogen Energy 36, pp. 3313-3321, 2011.

[23] ANTOLINI, E., COLMATI, F., GONZALEZ, E. R., "Ethanol oxidation on carbon supported ( $\mathrm{PtSn}$ )alloy/ $\mathrm{SnO}_{2}$ and $(\mathrm{PtSnPd})$ alloy $/ \mathrm{SnO}_{2}$ catalysts with a fixed $\mathrm{Pt} / \mathrm{SnO}_{2}$ atomic ratio: effect of the alloy phase characteristics", Journal Power Sources 193, pp. 555-561, 2009.

[24] SPINACÉ, E. V., NETO, A. O., FRANCO, E. G., et al., "Métodos de preparação de nanopartículas metálicas suportadas em carbono de alta Área superficial, como eletrocatalisadores em células a combustível com membrana trocadora de protons", Quimíca Nova 27, 4, pp. 648-654, 2004.

[25] STEVANOVIĆ, D. TRIPKOVIĆ, J. ROGAN, K., et al.,"Microwave-assisted polyol synthesis of carbon-supported platinum-based bimetallic catalysts for ethanol oxidation", Journal Solid State Electrochemistry, DOI 10.1007/s10008-012-1755-y, 2012. Article in press.

[26] MATIN, Md. A., JANG, J.-H, KWON, Y.-Uk, "PdM nanoparticles ( $\mathrm{M}=\mathrm{Ni}, \mathrm{Co}, \mathrm{Fe}, \mathrm{Mn})$ with high activity and stability in formic acid oxidation synthesized by sonochemical reactions", Journal of Power Sources 262, pp. 356-363, 2014.

[27] BERGAMASKI, K., GONZALEZ, E. R., NART, F. C., "Ethanol oxidation on carbon supported platinum-rhodium bimetallic catalysts", Electrochimica Acta 53, pp. 4396-4406, 2008.

[28] LEE, S., KIM, H. J., CHOI, S. M., et al., "The promotional effect of Ni on bimetallic PtNi/C catalysts for glycerol electrooxidation", Applied Catalysis A: General 429-430, pp. 39-47, 2012.

[29] NASSR, A. B. A. A., SINEV, I., GRÜNERT, W., et al, "PtNi supported on oxygen functionalized carbon nanotubes: In depthstructural characterization and activity for methanol electrooxidation", Applied Catalysis B: Environmental , v.142- 143, pp. 849- 860, 2013.

[30] DELPEUCH, A. B., MAILlaRD, F., CHATENET, M., et al., "Ethanol oxidation reaction (EOR) investigation on $\mathrm{Pt} / \mathrm{C}, \mathrm{Rh} / \mathrm{C}$, andPt-based bi- and tri-metallic electrocatalysts: A DEMS and in situ FTIR 
study", Applied Catalysis B: Environmental 181, pp. 672-680, 2016.

[31] SONG, P., LIU, L., WANG, A. J., et al., "One-pot synthesis of platinum-palladium-cobalt alloyed nanoflowers with enhanced electrocatalytic activity for ethylene glycol oxidation", Electrochimica Acta 164, pp. 323-329, 2015.

[32] LV, J-J, ZHENG, J.-N., WANG, Y.-Y., et al., "A simple one-pot strategy to platinumpalladium@palladium core-shell nanostructures with high electrocatalytic activity", Journal of Power Sources 265, pp. 231-238, 2014.

[33] ZHENG, J. N., LI, S. S., CHEN, F. Y., et al., "Facile synthesis of platinum-ruthenium nanodendrites supported on reduced graphene oxide with enhanced electrocatalytic properties", Journal of Power Sources 266, pp. 259-267, 2014.

[34] ALMEIDA, T.S., KOKOH, K.B., ANDRADE, A.R., "Effect of Ni on Pt/C and PtSn/C prepared by the Pechini method", International Journal of Hydrogen Energy 36, pp. 3803-3810, 2011.

[35] WANG, R., WANG, H., WANG, X., et al., "Effect of the structure of Ni nanoparticles on the electrocatalytic activity of $\mathrm{Ni} @ \mathrm{Pd} / \mathrm{C}$ for formic acid oxidation", International Journal of Hydrogen Energy 38 , pp. 13125 - 13131, 2013.

[36] HSIEH, C. T., YU, P. Y., TZOU, D. Y., et al., "Bimetallic Pd-Rh nanoparticles onto reduced graphene oxide nanosheets as electrocatalysts for methanol oxidation", Journal of Electroanalytical Chemistry 761, pp. 28-36, 2016.

[37] MAiYAlagan, T., AlAJE, T. O., SCOTT, K., "Highly Stable Pt-Ru Nanoparticles Supported on Three-Dimensional Cubic Ordered Mesoporous Carbon (Pt-Ru/CMK-8) as Promising Electrocatalysts for Methanol Oxidation”, Journal Physical Chemistry C 116, pp. 2630-2638, 2012.

[38] MUKHERJEE, P., ROY, P. S., BHATTACHARYA, S. K., "Improved carbonate formation from ethanol oxidation on nickel supported Pt-Rh electrode in alkaline medium at room temperature", International Journal of Hydrogen Energy 40, pp.13357-3367, 2015. 